\title{
NOTE
}

\section{An infectious viral disease of penaeid shrimp newly found in Korea}

\author{
J. H. Park ${ }^{1, *}$, Y. S. Lee ${ }^{1}$, S. Lee ${ }^{2}$, Y. Lee ${ }^{2}$ \\ ${ }^{1}$ Department of Laboratory Animal Science, College of Veterinary Medicine, Seoul National University, Suwon 441-744, Korea \\ ${ }^{2}$ Department of Biology, Seoul Women's University, Seoul 139-774, Korea
}

\begin{abstract}
Since 1993, massive mortalities have occurred among the penaeid shrimp Penceus orientalis cultured in Korea. The major gross findings of the naturally occurring cases were 2 to $6 \mathrm{~mm}$ sized white spots on the inside of the carapace and reddish discolorization. Amphophilic to basophilic intranuclear inclusion bodies were readily observed in the epithelia of epidermis, foregut, gills, and lymphoid organs. Electron microscopy revealed enveloped and nonoccluded ellipsoid to rod-shaped virus particles within the nucleus of lymphoid organ cells and the interstitial cells of the hepatopancreas of both naturally and experimentally infected shrimp. The size of the virions was $375 \times 167 \mathrm{~nm}$ and the nucleocapsid was $290 \times 75 \mathrm{~nm}$. The agent which caused ectodermal and mesodermal necrosis in penaeid shrimp in Korea resembled white spot syndrome virus (WSSV) found in Taiwan with respect to gross signs, histological changes and viral morphology. Its viral morphology differed from that of the rod-shaped nuclear virus of Penaeus japonicus (RV-PJ) found in Japan. However, a $643 \mathrm{bp}$ PCR product with an identical sequence to that from RV-PJ was detected. The results suggested that the Korean agent combined characters described for WSSV and RV-PJ.
\end{abstract}

KEY WORDS: Penaeus orientalis - White spot syndrome virus - RV -PJ · WSSV PCR

Since 1993, mortality exceeding $90 \%$ has occurred among Penaeus orientalis at shrimp farms on the southern and western coasts of Korea. Within 3 to $4 \mathrm{~d}$ after the first dead shrimp are observed, almost all of the shrimp in the pond die. Characteristic gross signs of the diseased shrimp are abnormal red discoloration of the body and white spots on the inside of the cuticle. Since 1993, a similar new disease, also causing white spots on the inside of the cuticle and high mortality, has been reported in Taiwan, Japan and Thailand (Inouye et al. 1994, Asian Shrimp Culture Council 1995, Lo et al. 1996). In Japan, the disease occurred in $P$. japonicus and caused massive economic loss (Inouye

·E-mail: pjhak@plaza.snu.ac.kr et al. 1994, Momoyama et al. 1995). By electron microscopy, a non-occluded bacilliform virus was observed in the lymphoid organs of affected shrimp, and was subsequently named rod-shaped nuclear virus of $P$. japonicus (RV-PJ). In Thailand (Wongteerasupaya et al. 1995), a cylindrical or ellipsoidal-shaped virus was observed by electron microscopy and named systemic ectodermal and mesodermal baculovirus (SEMBV). This virus was reported to infect $P$. monodon, $P$. orientalis, $P$. merguiensis, $P$. indicus, $P$. vannamei, and $P$. japonicus. A disease like SEMBV was reported in Taiwan and named white spot syndrome baculovirus (WSBV) because diseased shrimp showed characteristic white spots on the inside of the cuticle (Wang et al. 1995). All of these viruses have subsequently been grouped under the heading of white spot syndrome virus (WSSV) (Lightner 1996).

The causative agent for the disease causing similar gross signs in Korea has not been described or characterized and a diagnostic method for it is not yet available. As a result, there are no statistics for the losses that have resulted from it. The purpose of this study was to investigate this disease to determine its pathological characteristics and the causative agent.

Materials and methods. Source and preparation of specimens: Subadult Penaeus orientalis between 7 and $8 \mathrm{~cm}$ in size were collected from a shrimp farm at Taean in Chungchung Province located on the western coast of Korea. Moribund shrimps, which stayed at the edge of the pond, were collected and examined histologically with the light microscope. For histology, the cephalothorax was removed from each shrimp and fixed in Davidson's fixative for $1 \mathrm{wk}$. After fixation, it was cut into 4 pieces from the base of rostrum to the end of cephalothorax. Each piece was dehydrated serially with alchohol and embedded in paraffin wax. The pieces were then cut to $3 \mu \mathrm{m}$ and stained with hematoxylin and eosin (H\&E). 
Infection experiment: Thirty-seven healthy shrimp were incubated with 5 moribund shrimp. As a control, 10 healthy shrimp were kept in a separate aquarium. Aquaria were layered with $5 \mathrm{~cm}$ of sea sand at the bottom, filled with $15 \mathrm{l}$ of seawater, and equipped with an air stone. The shrimp were fed with a commercial brand of $10 \mathrm{~mm}$ pellets manufactured by Shinchon Feed Co. Ltd, Korea. The experiment was conducted at 25 to $28^{\circ} \mathrm{C}$.

Electron microscopy: The hepatopancreas from diseased shrimp was dissected and fixed in $2.5 \%$ glutaraldehyde in cacodylate buffer ( $\mathrm{pH} 7.2$ ) for 4 to $5 \mathrm{~h}$ at $4^{\circ} \mathrm{C}$. After washing in cacodylate buffer ( $\left.\mathrm{pH} 7.2\right)$, the samples were fixed in osmium tetroxide in cacodylate buffer $(\mathrm{pH} \mathrm{7.2)}$ for $100 \mathrm{~min}$ and then embedded in Epoxy 812. To observe lymphoid and epidermal tissue by electron microscopy, tissue was cut to $3 \mu \mathrm{m}$ from paraffin blocks and embedded in Epoxy 812. All specimens were cut to $70 \mathrm{~nm}$ with a diamond knifc.

Virus purification and extraction of viral DNA: Purification of virus and extraction of viral DNA were carried out as described previously (Wang et al. 1995, Takahashi et al. 1996) with a minor modification. Shrimp were rinsed with cold TE buffer $10 \mathrm{mM}$ Tris $\mathrm{HCl}_{1} 1 \mathrm{mM}$ EDTA, $\mathrm{pH}$ 7.6). The cephalothorax was then removed and soaked in cold extraction buffer (10 mM HEPES, $0.4 \mathrm{~N} \mathrm{NaCl}, 1$ mM EDTA, 1 mM EGTA (ethyleneglycol-bis-tetraacetic acid), 1 mM DTT (dithiothreitol), $2.5 \mathrm{mM}$ PMSF (phenylmethylsulfonylfluoride), $1 \mu \mathrm{g} \mathrm{ml}^{-1}$ leupeptin, $1.6 \mu \mathrm{g} \mathrm{ml}^{-1}$ pepstatin) and homogenized in a bead beater for 20 cycles of $20 \mathrm{~s}$ pulse and 20 s rest. The homogenate was centrifuged at $5000 \times g$ for $10 \mathrm{~min}$ and the supernatant was filtered through a $0.45 \mu \mathrm{m}$ membrane (cellulose acetate, Gelman Sciences). The filtrate was centrifuged at 100000 $\times g$ for $1 \mathrm{~h}$ at $4^{\circ} \mathrm{C}$. The pellet was then soaked in a small volume of TE buffer ( $\mathrm{pH} 8.0$ ) overnight at $4^{\circ} \mathrm{C}$. The pellet was gently resuspended and layered on top of a discontinuous gradient of 10 and $50 \%(\mathrm{w} / \mathrm{v})$ sucrose. The gradient was centrifuged at $100000 \times g$ for $1 \mathrm{~h}$ at $4^{\circ} \mathrm{C}$. A viral band was harvested with a pipet, washed with TE buffer, and centrifuged at $100000 \times g$ for $1 \mathrm{~h}$ at $4^{\circ} \mathrm{C}$. The viral genomic DNA was isolated from the pellet by incubating it in TE buffer containing $0.5 \%$ (w/v) SDS (sodium dodecyl sulfate), $1 \mathrm{mM}$ EDTA, and $1 \mathrm{mg} \mathrm{ml}^{-1}$ proteinase $\mathrm{K}$ at $55^{\circ} \mathrm{C}$ for $30 \mathrm{~min}$, followed by extraction with phenol-chloroform, and precipitation with ethanol.

Amplification of viral DNA by PCR: A primer pair developed by Takahashi et al. (1996) for amplification of a 643 base pair (bp) fragment from RV-PJ of Japan was used in our study. The primers were sense (5' GACAGAGATATGCACGCCAA 3') and antisense (5' ACCAGTGTTTCGTCATGGAG $3^{\prime}$ ). The reaction tube (total volume of $100 \mathrm{l}$ ) contained $2 \mu \mathrm{g}$ of viral ge- nomic DNA, 100 pmol of each primer, $200 \mu \mathrm{M}$ of each dNTP, $10 \mathrm{mM} \mathrm{KCl}, 20 \mathrm{mM}$ Tris-Cl (pH 8.8), $10 \mathrm{mM}$ $\left(\mathrm{NH}_{4}\right)_{2} \mathrm{SO}_{4}, 2 \mathrm{mM} \mathrm{MgSO}, 0.1 \%$ Triton $\mathrm{X}-100$, and $1 \mathrm{U}$ of Vent DNA polymerase (New England Biolabs, Inc., USA). The reaction tube was heated to $95^{\circ} \mathrm{C}$ for $1 \mathrm{~min}$ to denature DNA, then cooled to $37^{\circ} \mathrm{C}$ for $2 \mathrm{~min}$ (annealing temperature for the first 2 cycles) or $55^{\circ} \mathrm{C}$ (annealing temperature for the remaining 30 cycles). After annealing, the reaction tube was heated at $72^{\circ} \mathrm{C}$ for $2 \mathrm{~min}$, followed by further extension for $2 \mathrm{~min}$ at $72^{\circ} \mathrm{C}$ after the last cycle. A total of 32 amplification cycles were performed. Another primer pair developed by Lo et al. (1996) to amplify a 1447 bp fragment in WSSV genomic DNA was sense (5' TAATGCGGGTGTAATGTTCTTACGA 3') and antisense (5' ACTACTAACTTCAGCCTATCTAG 3'). The reaction buffer was identical to that described above. Amplification consisted of 1 cycle at a temperature of $94^{\circ} \mathrm{C}$ for $4 \mathrm{~min}$, $50^{\circ} \mathrm{C}$ for $1 \mathrm{~min}, 72^{\circ} \mathrm{C}$ for $3 \mathrm{~min}$, and then 39 cycles of $94^{\circ} \mathrm{C}$ for $4 \mathrm{~min}, 50^{\circ} \mathrm{C}$ for $1 \mathrm{~min}, 72^{\circ} \mathrm{C}$ for $3 \mathrm{~min}$, plus a final $5 \mathrm{~min}$ extension at $72^{\circ} \mathrm{C}$ after the 40 cycles. Polymerase chain reaction (PCR) products were analysed by electrophoresis in a $0.8 \%$ agarose gel.

Sequencing of PCR products: PCR products were purified from a gel slice using Geneclean II Kits (Bio

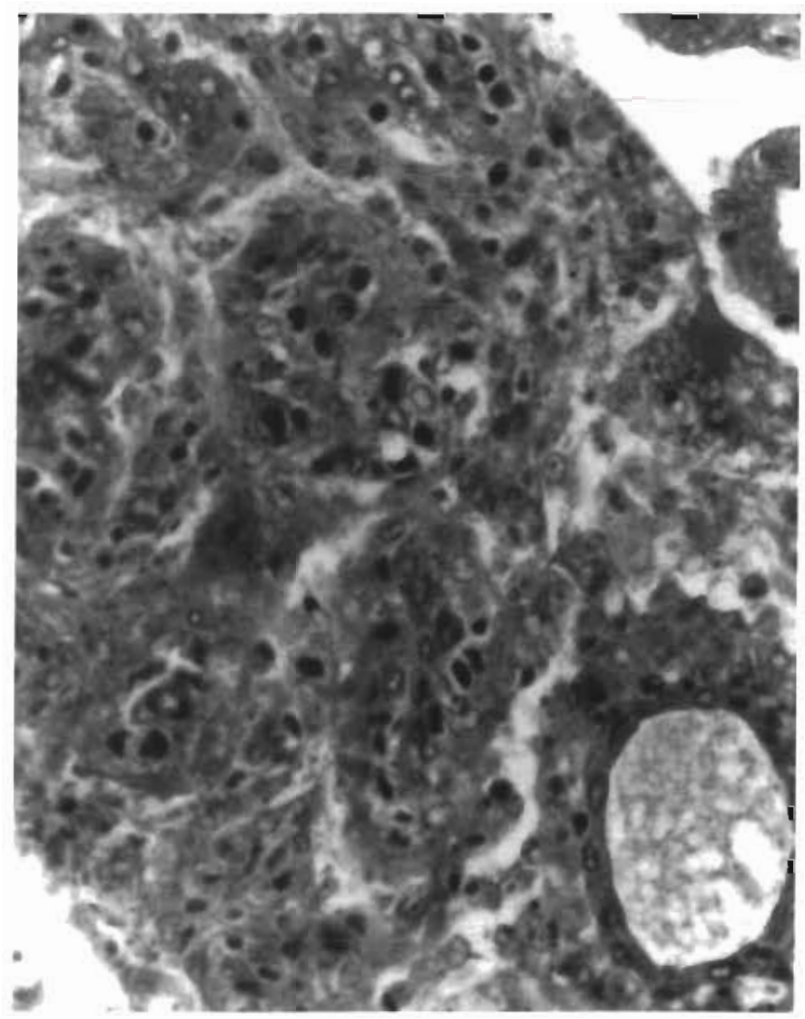

Fig. 1. Penaeus onientalis. Photomicrograph of infected lymphoid organ tissue with H\&E staining. Circular amphophilic or basophilic nuclear inclusions can be seen. (Magnification $\times 2711$ 
A

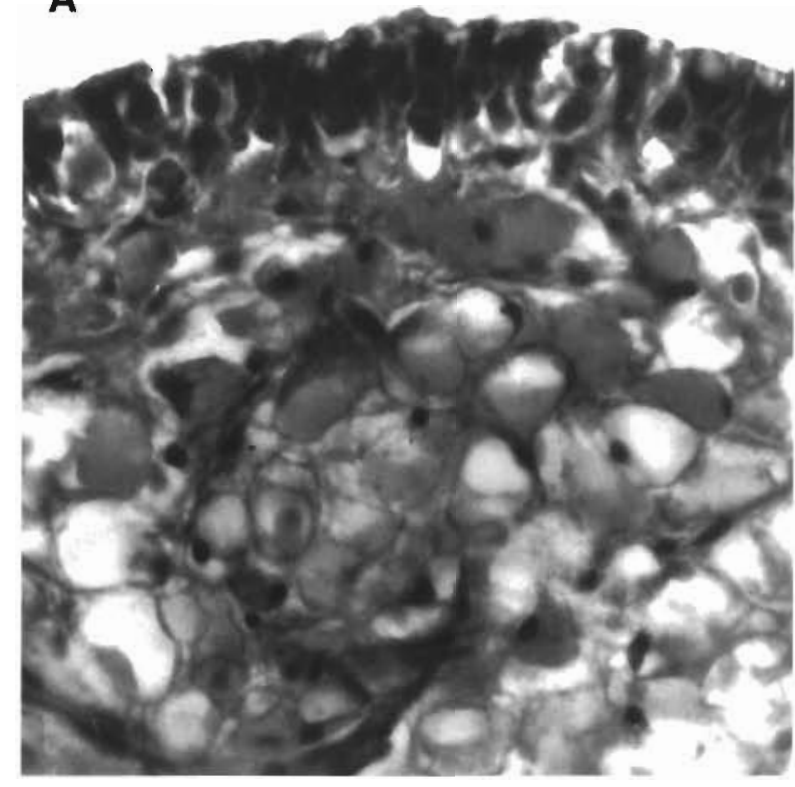

Fig. 2. Penaeus orientalis. Epithelia of $(A)$ infected epidermis and (B) foregut with $\mathrm{H} \& \mathrm{E}$ staining. Many epithelial cells are degenerating and intranuclear inclusion bodies can be seen. (Magnification $\times 551$ )

101, USA) and sequenced using an ABI PRISM Dye Terminator Cycle Sequencing Core Kit in an automatic DNA sequencer (Perkin-Elmer, USA).

Results and discussion. Experimentally infected shrimp started to show the same abnormal behavior as the pond-reared shrimp within 36 to $65 \mathrm{~h}$ after exposure to moribund pond-reared shrimp. They showed a characteristic S-shape swimming pattern, lethargy, anorexia, opaque musculature, and laterally recumbent posture and did not respond to touch. All the infected shrimp had died within $72 \mathrm{~h}$ post-exposure. No shrimp in the control group died during the course of the experiment.

Both pond-infected and experimentally infected shrimp exhibited white spots on the inside of the cuticle over the cerebrothorax and red body coloration. Except for these changes, there were no other visible changes in either the pond-infected or experimentally infected shrimps. For both, histological changes were observed in the lymphoid organ, epidermis, gills, and foregut. The stromal cells of the lymphoid organ were massively necrotic (Fig. 1). The epithelia of the tubules were also necrotic, resulting in the destruction of tubular structure. The epidermis was also degenerated or necrotic (Fig. 2A). Many circular amphophilic or basophilic nuclear inclusions were observed in the nuclei of the degenerating epithelial cells. There was

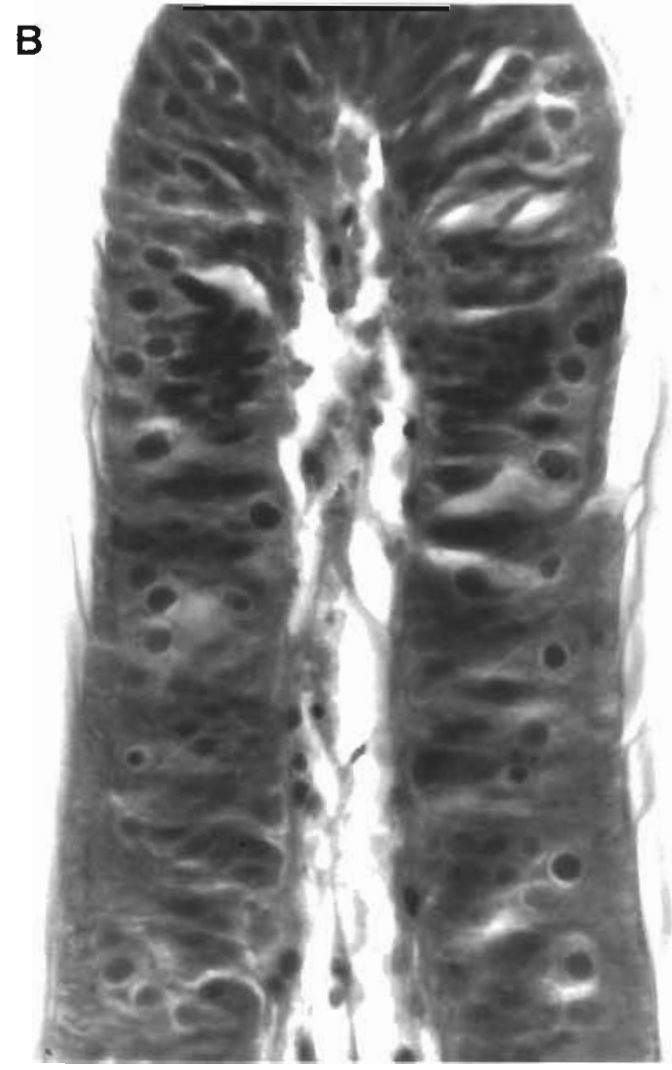

an unstained space between the inclusion body and chromatin which was concentrated at the nuclear membrane. Cells with a nuclear inclusion body and degenerating cells showed minute basophilic granules in the cytoplasm. Cellular debris was attached to the

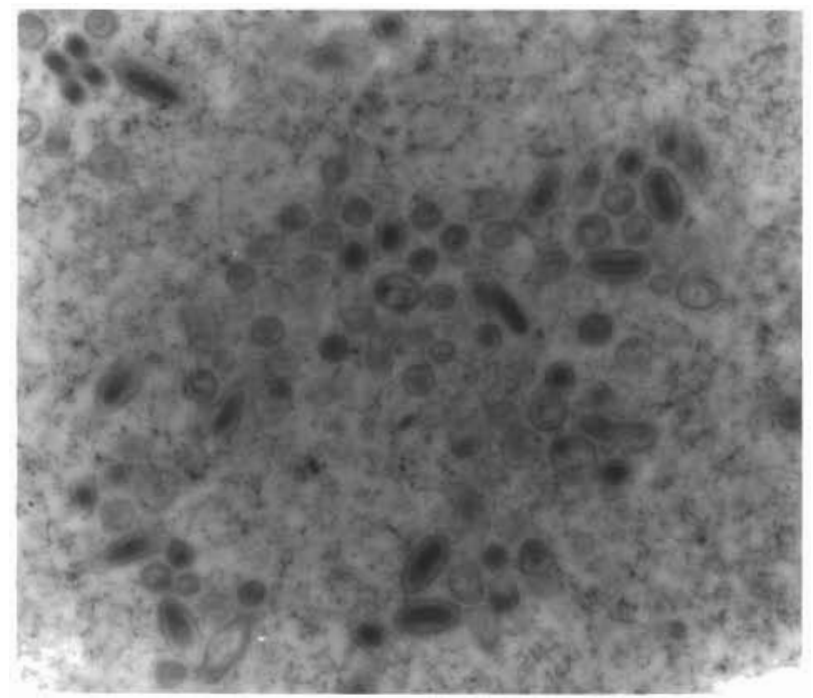

Fig. 3. Penaeus orientalis. Electron micrograph of the nucleus of a hepatopancreatic interstitial cell from an infected shrimp. Rod- or oval-shaped enveloped viral particles can be seen. (Magnification $\times 25000$ ) 

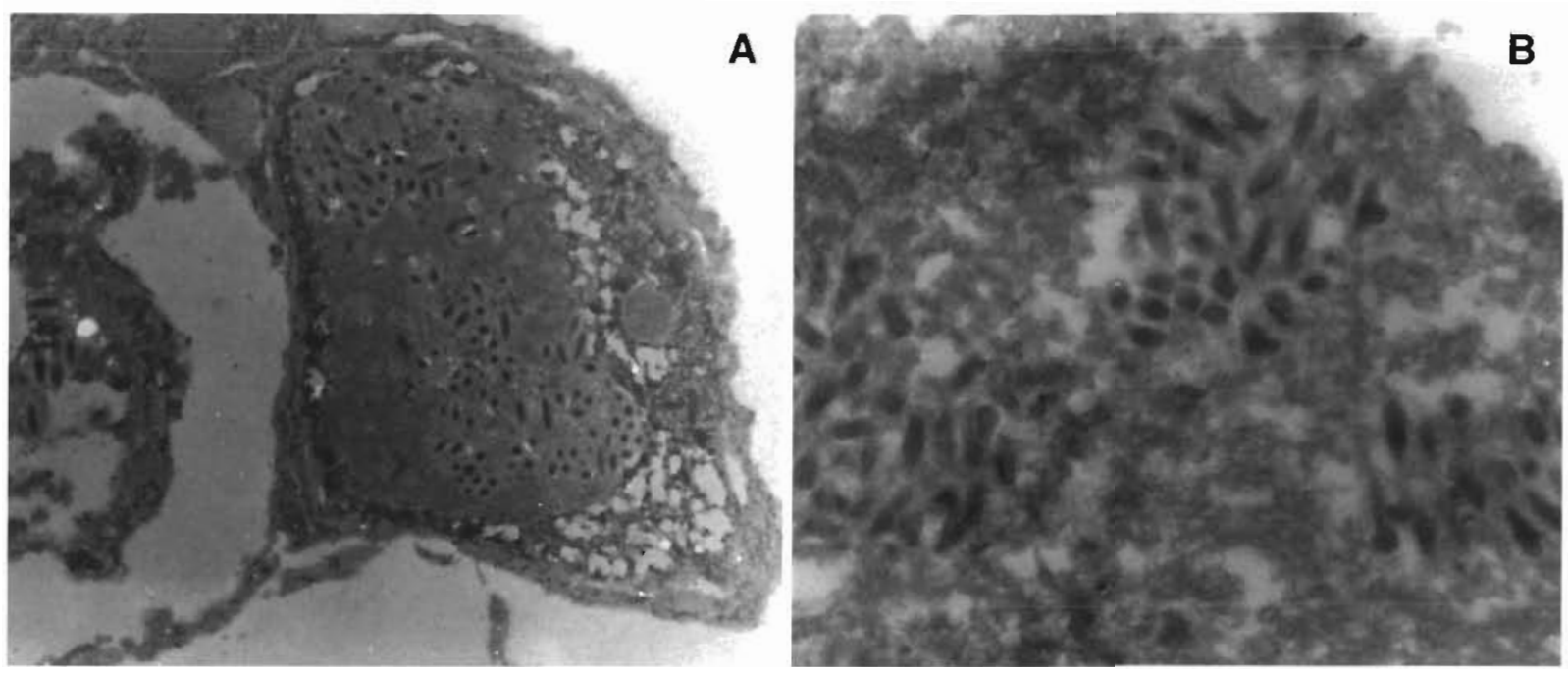

Fig. 4. Penaeus orientalis. Electron micrograph of nuclei of infected stromal cells of (A) the iymphoid organ (maagnification $\times 28500$ ) and $(B)$ the epidermis (magnification $\times 15400$ ). Rod-shaped enveloped virus particles can be seen

inside of the cuticle. Intranuclear inclusion bodies were also observed in epithelia of the gills and foregut (Fig. 2B). There was no lymphocytic infiltration in the area of degenerating and necrotic cells and no change in the epithelium of the hepatopancreas. Some of the interstitial cells of the hepatopancreas contained amphophilic intranuclear inclusion bodies. By means of electron microscopy, rod-shaped, enveloped virons were found in some of the interstitial cells of the hepatopancreas (Fig, 3). Virus particles were also observed in many nuclei of lymphoid organ stromal cells (Fig. 4A). In addition, inclusion bodies in the epidermal cells were identified as a clusters of viral particles (Fig. 4B). The size of the virions $(167 \times 375 \mathrm{~nm})$ and the nucleocapsid $(290 \times 75 \mathrm{~nm})$ (Fig. 4) was much larger than that reported for RV-PJ found in Japan ( $83 \times$

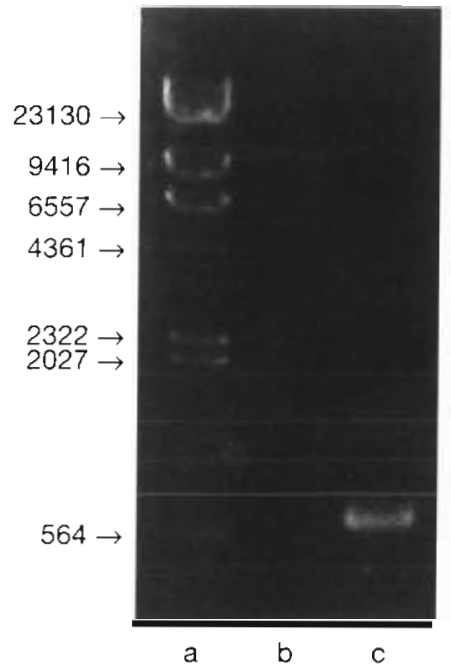

Fig. 5. Ethidium bromidestained agarose gel of PCR-amplified fragments. Primers specific for RV-PJ were used for the reaction using DNA template prepared from normal (lane b) and moribund (lane c) Penaeus orientalis. Lane a: DNA size markers labeled in base pairs
$275 \mathrm{~nm}$ ). However, it was similar to WSSV found in Taiwan (Lo et al. 1996), which is spindle- or rodshaped, is 70-150 $\times 250-380 \mathrm{~nm}$ in size, and has double-stranded DNA of $150 \mathrm{kbp}$. However, PCR with primers specific to RV-PJ gave a PCR product with the expected size of $643 \mathrm{bp}$ (Takahashi et al. 1996) whereas PCR primers specific to WSSV (Lo et al. 1996) gave no product (Fig. 5). When the nucleotide sequence of the $643 \mathrm{bp}$ PCR product was determined, it showed $100 \%$ homology to the one reported by Takahashi et al. (1996). Thus, analysis of these Korean shrimp revealed some characteristics of RV-PJ and some of WSSV, and it clearly would seem to belong to the white spot virus complex as delimited by Wang et al. 1995). It could be that the Korean virus is a distinct strain or that our material was infected with both RVPJ and WSBV-like strains but that we could detect only RV-PJ by PCR. Further work will be required to distinguish amongst these possibilities. In the interim, the primers developed by Takahashi et al. (1996) may be useful in diagnostic and epidemiological studies with diseased Korean shrimp.

Acknowledgements. This work was supported by a grant from the Korea Research Foundation.

\section{LITERATURE CITED}

Asian Shrimp Culture Council (1995) Mass mortality caused by systemic bacilliform virus in cultured penaeid shrimp, Penaeus monodon, in Thailand. Asian Shrimp News 21: $2-4$

Inouye $\mathrm{K}$, Miwa $\mathrm{S}$, Oseko N, Nakano $\mathrm{H}$, Kimura $\mathrm{T}$, Momoyama K, Hiraoka M (1994) Mass mortality of cultured 
kuruma shrimp Penaeus japonicus in Japan in 1993: electron microscopic evidence of the causative virus. Fish Pathol 29:149-158

Lightner DV (ed) (1996) A handbook of pathology and diagnostic procedures for diseases of penaeld shrimp. World Aquaculture Society, Baton Rouge, LA

Lo $\mathrm{CF}$, Leu $\mathrm{JH}, \mathrm{Ho} \mathrm{CH}$, Chen $\mathrm{CH}$, Peng SE, Chen YT, Chou CM, Yeh PY, Huang SJ, Chou HY, Wang CH, Kou GH (1996) Detection of baculovirus associated with white spot syndrome (WSBV) in penaeid shrimps using polymerase chain reaction. Dis Aquat Org 25:133-141

Momoyama K. Hiraoka M. Inouye K, Kimura T, Nakano H (1995) Diagnostic techniques of the rod-shaped nuclear virus infection in the kuruma shrimp, Penaeus japonicus Fish Pathol 30:263-269

Takahashi Y, Itami T, Maeda M, Suzuki N, Kasornchandra J Supamattaya K, Khongpradit R, Boonyaratpalin S, Kondo

Editorial responsibility: Timothy Flegel

Bangkok, Thailand
M, Kawai K, Kusuda R, Hirono I, Aoki T (1996) Polymerase chain reaction (PCR) amplification of bacilliform virus (RV-PJ) DNA in Penaeus japonicus Bate and systematic ectodermal and mesodermal baculovirus (SEMBV) DNA in Penaeus monodon Fabricus. J Fish Dis 19:339-403

Wang $\mathrm{CH}$, Lo CF, Leu JH, Chou CM, Yeh PY, Chou HY, Tung MC, Chang CF. Su MS, Kou GH (1995) Purification and genomic analysis of baculovirus associated with white spot syndrome (WSBV) of Penaeus monodon. Dis Aquat Org 23:239-242

Wongteerasupaya C, Vickers JE, Sriurairatana S, Nash GL, Akarajamorn A, Boonsaeng V, Panyim S, Tassanakajon A, Withyachumnarnkul B, Flegel TW (1995) A non-occuluded, systemic baculovirus that occurs in cells of ectodermal and mesodermal origin and causes high mortality in the black tiger prawn Penaeus monodon. Dis Aquat Org 21:69-77

Submitted: August 25, 1997; Accepted: May 25, 1998 Proofs received from author(s): August 25, 1998 